\title{
PATH ANALYSIS RISK FACTORS THAT INFLUENCE MATERNAL MORTALITY IN DISTRICT OF BREBES
}

\author{
Masturoh $^{1)}$, Supriyadi Hari Respati²), Bhisma Murti1) \\ ${ }^{1)}$ Masters Program in Public Health, Sebelas Maret University \\ 2)Department of Obstetrics and Gynecology, Dr. Moewardi Hospital, Surakarta
}

\begin{abstract}
Background: Maternal mortality is one of health indicators of a country. Based on demographic and health survey in Indonesia in 2012, the data presented the fact that there was a significant increase on maternal mortality which was 359 maternal mortality in every 100,000 live births. Maternal mortality rate indicated a decrease to 305 maternal mortality in every 100,000 live births which was stated as a finding in Intercensal Population Survey in 2015. District of Brebes was one of the districts in the province of Central Java which had the highest maternal mortality in 2016 which was 54 maternal mortality. This study aimed to reveal the risk factors that influence maternal mortality.
\end{abstract}

Subjects and Method: This was an analytic observational study with case control design. This study was conducted in Brebes District, Central Java, from February to March 2017. A sample of 162 subjects, consisting of 54 cases of all mothers who died as part of Maternal Mortality Rate in District of Brebes during 2016, and were recorded in District of Brebes' Health Institutions, Central Java and 108 controls subjects were taken from cohort registry and verbal autopsy documents at the Community Health Centre whereby a case of maternal mortality existed, were selected in this study by fixed disease sampling. The dependent variables were maternal mortality, and the independent variables were maternal education, maternal job, numbers of visits to Antenatal Clinic (ANC), birth attendant, place of delivering babies, high-risk pregnancy, obstetric complications. The data were analyzed by path analysis model.

Results: The results of this research indicated that the risk factors which directly influenced maternal mortality were the amount of visits to $\mathrm{ANC}<4$ times $(\mathrm{b}=0.25 ; 95 \% \mathrm{CI}=0.07$ to $0.42 ; \mathrm{p}=0.006)$ and obstretical complications $(b=1.78 ; 95 \% \mathrm{CI}=1.85$ to $0.14 ; \mathrm{p}=0.013)$. High level of education $(b=-0.63 ; 95 \% \mathrm{CI}=-0.91$ to $0.34 ; \mathrm{p}=0.001)$ and maternal jobs $(\mathrm{b}=$ $1.00 ; 95 \% \mathrm{CI}=0.34$ to $1.67 ; \mathrm{p}=0.003$ ) were influenced their numbers of visits to ANC.

Conclusion: Amount of visits to $\mathrm{ANC}<4$ times and obstretical complications are influenced maternal mortality. High level of education and maternal jobs are influenced their numbers of visits to ANC.

Keywords: maternal mortality, risk factors, case control, path analysis

Correspondence: Masturoh. Masters Program in Public Health, Sebelas Maret University, Jl. Ir. Sutami 36 A, Surakarta 57126, Central Java, Indonesia. Email: masturoh.bmd@gmail.com. Mobile: +628783000101. 